\title{
CONTRIBUTIONS FOR THE PPK DURING ECONOMIC SHUTDOWN
}

\begin{abstract}
The subject of analysis are issues tied to contributions for the employee capital plans during a period of economic shutdown. Employee capital plans (PPK), covered under the so-called third pillar of social security, serve as a means to collect additional funds that are disbursed after the end of professional activity. The funds collected in the PPK come primarily from contributions made by the employer and by the participant of the PPK. These contributions are not made during the period of economic shutdown, within the meaning of anti-crisis regulations of 2013. This paper discusses the consequences of suspension of contributions for the employee capital plans for their participants. The author discusses also the obligation to make contributions into the plans during the period of economic shutdown caused by the spread of COVID-19.
\end{abstract}

Słowa kluczowe: pracowniczy plan kapitałowy, wpłaty, przestój ekonomiczny

Keywords: employee capital plan, contributions, economic shutdown

ASJC: 3308 , JEL: K31

\section{Introduction}

The employee capital plans (PPK) have been functioning in the economic system as of 1 July 2019, under the so-called third pillar of social security. Pursuant to Art. 3 section 1 of the Act of 4 October 2018 on employee capital plans Dz.U. 2020, item 1342 consolidated text, hereinafter referred to as: "the Act on PPK," these institutions are long-term saving schemes for their participants, meant to systematically save funds that would be disbursed after the participant reaches the age of 60. The main objective of the PPK is to increase the income of the employees after they end their professional activity. On the basis of an exception, the accumulated funds may be used to cover one's own contribution when taking out a loan for the purchase of an apartment, construction or reconstruction of a residential building. However, in such case they need to be repaid, in the nominal amount, within a period not longer than 15 years from the date of disbursal 
(Art. 98 of the Act). Up to $25 \%$ of the accumulated funds can be used to cover the costs of medical treatment in the case of serious illness of the participant of the PPK, his/her spouse or child (Art. 101 of the Act on employee capital plans).

The savings accumulated in the employee capital plan come primarily from the obligatory contributions paid made by the employer and by the participant of the PPK. Both parties have the opportunity to make additional, voluntary contributions. The basic contribution, financed by the employer, is set at $1.5 \%$ of the participant's salary, and the declared voluntary optional contributions may not exceed $2.5 \%$ of this salary (Art. 26 of the Act on employee capital plans). The amount of optional, voluntary contribution to which the individual employees are entitled may be determined on the basis of seniority with the given employer, or on the basis of other criteria, set in the collective labour agreement or in the salary regulations. The basic contributions of participants, as a rule, amount to $2 \%$ of salary. For persons with low salaries-not exceeding, from various sources, the level of 1.2 of the minimum wage-the contributions may be lower, but not lower than $0.5 \%$ of their gross salary. The optional contributions by employees should be under $2 \%$ of their remuneration (Art. 27 of the Act on employee capital plans). The contributions into the PPK are calculated on the same the basis as the one used for the assessment of pension and disability insurance contributions of a given participant, referred to in the Act on social insurance (Act of 13 October 1998 on the Social Insurance System, Dz.U. 2020, item 266 consolidated text), without the limitation specified in Art. 19 section 1 of this Act, and excluding the basis for assessment of contributions for the same insurance with respect to persons on parental leave and receiving maternity allowance or benefits equal to maternity allowance. The regulations on PPK provide also for a one-off welcome payment and annual subsidies from the state budget. At the same time, the Act stipulates that the maximum limit of contributions and subsidies that can be made into all accounts of a participant of the PPK during a calendar year is capped at the Polish zloty equivalent of $\$ 50,000.00$, converted according to the average exchange rate of the US dollar published by the National Bank of Poland on the last business day before 31 December of the year preceding the given calendar year. When this limit is exceeded, no further contributions and subsidies are made into the account of the given participant of the employee capital plan (Art. 25a section 1 of the Act on employee capital plans). ${ }^{1}$ In other words, when the amount permitted in the given calendar year is accumulated in the account of the given participant, further contributions are suspended until the end of the year. Contributions financed by the employer and by the participant of the PPK are suspended also in the situations listed in Art. 25 section 4 of the Act on employee capital plans. These situations include, among others, economic shutdown, referred to in Art. 2 item 1 of the Act of 11 October 2013 on special solutions tied to protection of jobs (Dz.U. 2019, item 669 consolidated text, hereinafter referred to as "the Anti-Crisis Act of 2013"). Having in

\footnotetext{
1 Provision added by the Act of 16 May 2019 on amendment of the Act on employee capital plans, the Act on the organization and functioning of pension funds and the Banking Law Act, Dz.U. 2019, item 1074.
} 
mind the situation in which many employers find themselves in the times of the coronavirus, it is necessary to consider two questions: what consequences for the participants are associated with the suspension of contributions into the PPK, and whether an employer who struggles with economic difficulties caused by the spread of COVID-19 can profit from the suspension of the obligation to make contributions into the PPK.

\section{Exemption from contributions into the PPK}

Pursuant to Art. 25 section 4 item 1 of the Act on employee capital plans, the employer and the participant of the PPK do not finance the basic contribution, nor the optional contribution, during the period of economic shutdown referred to in the Act on protection of jobs. The contents of the provision referred to above clearly states that as a rule, the financing of contributions into the PPK is suspended for the period of economic shutdown. This applies primarily to amounts contributed by the employer. The situation is different in the case of contributions financed by the participant. The participant may, in a declaration submitted to the employer, declare that he/she shall finance the basic contribution and the optional contribution (section 5), which means that the final decision in that respect is taken by the employee. The employee may declare that he/she would pay the basic contribution and the optional contribution, or just one of them. Nothing hinders the participant from paying only the optional contribution during the period of economic shutdown. A participant of the employee capital plan, who declares the will to make contributions into the PPK during a period of economic shutdown, is obliged to file a declaration authorizing the employer to deduct the appropriate amounts from his/her salary.

The question arises whether the employee, profiting from the opportunity specified in Art. 25 section 5 of the Act on the employee capital plans is bound by the statutory limits regarding the level of individual contributions. There is no doubt that the participant may not exceed maximum amounts set by the legislators. He or she is not bound by the limitations regarding minimum basic contributions. By the reasoning $a$ minori ad maius, it should be recognized that since the participant is not obliged to make basic contributions during the period of economic shutdown, he or she is even more so entitled to make contributions in amounts lower than provided in Art. 27 sections 1 and 2 of the Act on the PPK. During the period of economic shutdown, the PPK participant is therefore entitled to make the basic contribution in an amount even lower than $0.5 \%$ of his/her salary-also in a situation where his/her salary exceeds the threshold of 1.2 times the minimum wage.

Contributions due from the employer and the PPK participant are calculated at the time of payment of salary (Art. 28 section 3 of the Act on PPK). Analyzing the contents of the indicated provision in the context of provisions of Art. 25 (4) (1) of the Act on PPK it is necessary to state that exemption from the financing of basic and optional contributions applies to benefits paid during the period of economic shutdown, 
irrespective of the period for which the given remuneration is due. The remuneration due for the time preceding the time of economic shutdown does not constitute the basis for calculation of contributions into the employee capital plan if it is paid already after the shutdown was introduced. Whereas the employer shall be obliged to calculate contributions on salary due for work performed during the period of shutdown, if this salary is paid after the end of the shutdown.

The suspension of contributions financed by the employer and the participant of the PPK during the period of economic shutdown is relevant also from the perspective of the welcome payment and the annual subsidies. The former, pursuant to Art. $31 \mathrm{sec}-$ tion 1 of the Act on PPK, is available for persons who participate in the PPK for at least 3 full calendar months, provided that during the period of participation, basic contributions financed by the participant were made for at least 3 months. The right to the welcome payment is subject to the fulfilment of two conditions: participation in the employee capital plan for at least 3 full calendar months and the transfer of the basic contributions due from the participant for 3 months to the financial institution managing the accumulated funds.

With respect to the required term of participation in the PPK, it is irrelevant whether the given person joined the PPK during the period of economic shutdown, or at any other time. This condition is met by a participant who can demonstrate three full months of participation. A resignation, during the period of shutdown, from the payment of basic contributions, may result in the later vesting of right to the welcome payment. The participant will be able to claim the welcome payment only after he/she transfers to the PPK the basic contributions due for at least 3 months. It is worth noting that the amount of paid basic contributions is irrelevant here. Thus, the transfer of even small amounts to the financial institution shall entitle the participant to the payment defined in Art. 31 of the Act on PPK.

The situation is different in the case of annual subsidy. Pursuant to Art. 32 section 2 of the Act on PPK, the PPK participant is entitled to the annual subsidy if the amount of the basic and optional contributions financed by the employer and by the PPK participant in the given year is equal to at least the basic contributions due on an amount equal to 6 times the minimum wage in force during the given year. In the case of a participant who receives from various sources remuneration not higher than 1.2 times the minimum wage, the annual subsidy is granted when the amount of basic and optional contributions made by the employer and the PPK participant during the calendar year is equal to at least $25 \%$ of the amount of basic contributions due on an amount equal to 6 times the minimum wage in force during the given year. The granting of the annual subsidy is conditioned upon the value of contributions financed by the employer and the PPK participant, transferred to the financial institution during the given calendar year. As a rule, the claim for subsidy may be raised by a participant whose account was credited with an amount corresponding to at least the value of basic contributions, calculated on the amount being 6 times the minimum wage. In the case of persons with low salaries, not higher than 1.2 times the minimum wage, it is required that contributions 
equal to at least $25 \%$ of that amount must be transferred to the financial institution. The period of participation in the PPK remains irrelevant in that respect, which means that the annual subsidy may be claimed by an employee already after a month after joining the employee capital plan.

Article 32 section 2 of the Act on PPK discusses basic contributions due on the amount being 6 times the minimum wage, without referring to the financing entity. Therefore, it should be assumed that the provision refers to obligatory contributions both from the employer and the PPK participant. Having in mind the provisions of Art. 26 section (1) and Art. 27 section (1) of the Act on the PPK, in order to be entitled the annual subsidy, the participant must have collected in his account in the given calendar year an amount equal to at least 3.5\% of the amount being 6 times the minimum wage. As the minimum wage for 2021 is set at PLN 2800.00, the value of contributions into the PPK, entitling the participant to annual subsidy, cannot be lower than PLN 588.00.

In summary, with relation to suspension of contributions into the PPK during the time of economic shutdown, the capital accumulated in the account of the participant does not increase. The participant may become entitled to the welcome payment later than normally, and in some cases, the given person may be deprived of his/her entitlement to annual subsidy.

\section{Economic shutdown}

The suspension of financing of the basic and optional contributions made by the employer and by PPK participants covers the period of economic shutdown within the meaning of Art. 2 (1) of the Anti-Crisis Act of 2013. According to the indicated provision, economic shutdown is the period during which the employee does not perform work, for reasons not associated with the employee who remains ready to work. Thus, the economic shutdown occurs when the following conditions are met: periodic nonperformance of work; inability to perform work for reasons not associated with the employee; and the employee remains ready to work.

The condition of non-performance of work refers to employee obligations under the employment contract. This conclusion stems from the provision of Art. 4 (1) of the Anti-Crisis Act of 2013, which stipulates that the collective labour agreement or another agreement between the employer and the employees determines the conditions and manner for performing work during the period of economic shutdown. Thus, the legislator does not require the employer to abstain from all kinds of activity. Cleaning or maintenance works can be performed during the time of economic shutdown.

Reasons not associated with the employee, which make it impossible for him/her to perform his/her work, include circumstances associated with the employer, or independent of the parties of the employment relationship. Reasons associated with the employer should not be interpreted narrowly as reasons caused by or reasons attributable 
to the employer (judgment of the Supreme Court of 7 January 2014, I PK 150/13, OSNP 2015, No. 3, item 35; judgment of the Supreme Court of 25 October 2016, I PK 255/15, LEX 2155205). Events not associated with the employee include economic causes tied to such circumstances as decreased demand for goods produced or services provided by the employer, organizational or technological causes, events caused by a force majeure (natural disasters). However, circumstances affecting the employee, regardless of whether the employee is at fault or not, cannot be considered as such (Pisarczyk 2013, p. 626).

Moreover, the employee is required to be ready for work. This readiness is understood as: 1) intention to perform work, 2) actual ability to perform work, 3) manifesting readiness to perform work and 4) being at the employer's disposal, on standby duty, at the workplace or at any other place designated by the employer (Kijowski 1978, pp. $47 \mathrm{ff}$; judgment of the Supreme Court of 25 October 2016, I PK 255/15, LEX 2155205). The employee must demonstrate a subjective intention to perform the agreed work, supported by an objective physical and mental capacity to perform it (judgment of the Supreme Court of 7 July 2016, I PK 185/15, LEX 2111405). Thus, the employee should be prepared to immediately undertake work to which he/she shall be called. This criterion is not met by an employee who has been suspended from work as a preventive measure (judgment of the Supreme Court of 16 August 2005, I PK 32/05, OSNP 2006, No. 11-12, item 184), or who encountered obstacles in the performance of his/her duties under the employment relationship due to cessation of the company's operation resulting from its actual liquidation (judgment of the Supreme Court of 24 October 1997, I PKN 280/97, OSNP 1998, No. 15, item 453).

The definition of economic shutdown speaks of the "employee." As the Anti-Crisis Act of 2013 does not regulate precisely the understanding of this term, it should be assumed that it refers to persons defined in Art. 2 of the Labour Code. The Act on PPK grants the right to participate in the employee capital plan not only to employees, but also to other hired persons, named in Art. 2 (18). This right may be exercised in particular by persons performing work on the basis of civil law contracts, persons carrying out home-based work, members of agricultural cooperatives. Therefore, it can happen that the employee capital plan would be established by an entity which hires only persons who do not have the status of employee. This raises doubt whether such entity can be subject to the rules of economic shutdown, provided for under the Anti-Crisis Act of 2013.

It is worth noting that the Anti-Crisis Act of 2013 covers entrepreneurs within the meaning of the Act-Law on Entrepreneurs or the Act on Freedom of Business Activity, who meet the conditions set forth in Art. 3 (1) and (1a) of the Act. The latter ones include such factors as decrease in turnover, no arrears in payment of public liabilities, no grounds for bankruptcy. An entrepreneur who meets the conditions set out in the Act has the possibility to profit from certain aid instruments during economic shutdown. These instruments include funds from the Guaranteed Employee Benefits Fund, used to partly finance the salary due to employees for the time of shutdown, and the payment of the employer's part of the social security contributions. As both the definition 
of economic shutdown and further provisions of the Act refer to employees, an entrepreneur who is not an employer cannot profit from solutions that directly serve to protect jobs (Art. 3 of the Labour Code). However, there is no doubt at all that such entrepreneur can also be affected by economic problems tied to decrease in the sales of goods and services, to the extent defined in the Anti-Crisis Act. In order to overcome the crisis, the entrepreneur may make a decision that his/her employees would temporarily not perform work, but would remain ready to work. Suspension or reduction of business activity by the given entrepreneur cannot be qualified as economic shutdown referred to in Art. 2 (1) of the Anti-Crisis Act of 2013. In consequence, on top of the inability to profit from solutions provided for under the Anti-Crisis Act, such entrepreneur would not be authorized to suspend contributions into the PPK. In that respect, the Act on PPK requires amendment. The principle of equality speaks in favour of exempting from contributions to employee capital plans also those entrepreneurs who only hire persons without employee status.

Another important issue is whether the suspension of financing of basic and optional contributions is open only to entrepreneurs. As Art. 25 (4) of the Act on PPK refers to the "employing entity", it should be assumed that all entities covered by the Act on PPK are exempted from the obligation to finance contributions (Art. 2 (1) (21) of the Act on PPK), regardless of their legal status. In consequence, during the period of economic shutdown an employer who is not an entrepreneur is relieved only of the obligation (Bigaj 2020, pp. 184-185) to pay contributions into the PPK. The entrepreneur who meets the conditions set forth in Art. 3 (1) and (1a) of the Anti-Crisis Act of 2013 may additionally apply for benefits provided for under that Act.

Economic shutdown within the meaning of Art. 2 (1) of the Anti-Crisis Act is referred to also in Art. 15g (5) of the Act of 31 March 2020 on amending the Act on special solutions associated with the prevention, counteracting and control of COVID-19, other infectious diseases and the crisis situations they cause, as well as certain other acts (Dz.U. 2020, item 374 as amended, hereinafter referred to as: "the Anti-Crisis Shield"). The contents of sections 1 and $1 \mathrm{a}$ of this provision states that the economic shutdown may affect employees performing work for an entity which suffered a decrease in turnover or in revenues as a result of COVID-19. The term "employee" is used by the legislator to denote persons indicated in Art. 2 of the Labour Code, and the legislator stipulates simultaneously that provisions of sections 1 and 1a are applied accordingly to persons employed under other legal grounds, such as contract of mandate, contract to provide services (Art. 15 (4) of the Anti-Crisis Act). Analysis of Art. 15g of the AntiCrisis Shield leads to the conclusion that in this case, economic shutdown is understood as the period when employees and other hired persons are unable to perform work due to difficulties related to the spread of the coronavirus, but they remain ready for work. In terms of legal structure, this definition is similar to economic shutdown defined in the Anti-Crisis Act of 2013. However, significant differences can be perceived between these two institutions. They concern, apart from the subjective aspect, the manner of introducing economic shutdown and the reasons for its introduction. 
Pursuant to Art. 4 (1) of the Anti-Crisis Act of 2013, the conditions and the manner for performing work during the period of economic shutdown are laid down in the collective labour agreement, or in the agreement negotiated with representation of employees. In the case of the collective labour agreement, the social partners are obliged to respect the rules laid down in the Labour Code. In the Anti-Crisis Act, the legislator refers only to a collective agreement.

According to the statutory regulation, the entity authorized to represent employees during negotiations conducted in order to conclude the said agreement is, first of all, the company trade union organization which meets the requirements set forth in Art. $25^{1}$ of the Act of 23 May 1991 on Trade Unions (Dz.U. 2019, item 263, hereinafter referred to as: "the Act on Trade Unions"). If there are more such organizations, it is required that the contents of the agreement are consulted with and approved by all the trade unions. As the Anti-Crisis Act of 2013 does not contain detailed regulations regarding the cooperation of trade union organizations, in this respect it is necessary to refer to rules laid down in Art. 30 (4) of the Act on Trade Unions. If agreeing the content of the agreement with all the company trade union proves impossible, the entrepreneur enters into an agreement with the representative trade unions within the meaning of Art. $25^{3}$ (1) or (2) of the Act on Trade Unions. Each such organization should associate at least $5 \%$ of the company's employees. If there are no company trade unions at the given entrepreneur, the right to represent the staff in negotiations to conclude an agreement is vested in the representatives of the employees selected in the procedure adopted at the given company.

Copy of the collective agreement is enclosed with the application for the granting of aid benefits.

The introduction of economic shutdown is regulated slightly differently by Art. 15g (11) of the Anti-Crisis Shield. It is done on the basis of an agreement concluded between the employer and representation of the employed. The latter is formed by: 1) representative union organizations within the meaning of Art. $25^{3}$ (1) or (2) of the Act on Trade Unions. Priority in that respect is ensured for organizations each of which associates at least $5 \%$ of employees hired by the employed. In the absence of organizations meeting the representation criterion, the right to negotiate the agreement is vested in the company union organization. In the case of employers where there are no trade unions, the agreement is concluded by representatives of the employees, selected in accordance with the procedure adopted by the employer in question. The employer is obliged to deliver a copy of the agreement to the relevant district labour inspector. In the case of employees covered by a group or sectoral collective labour agreement, information on the agreement is also delivered to the registered of group/sectoral labour agreements (Baran 2020, pp. 196-198).

Comparing the institutions provided for in the 2013 and 2020 regulations, it should be noted that the economic shutdown discussed in the Anti-Crisis Shield is not subject to agreements. The legislator reversed the sequence of trade unions which are authorized to conclude an agreement which determines the conditions and manner for performing 
work during the period of economic shutdown. The reasons for non-performance of work by the employed are also defined more narrowly: it is required that they have to be the consequence of occurrence of COVID-19. In my opinion, the issues tied to the manner of introduction of economic shutdown and to the grounds for its introduction are relevant only from the standpoint of aid benefits which the given employer may apply for. The entrepreneur, or another entity referred to in Art. 15g (1) and (1a) of the Anti-Crisis Shield, who suffered a decline of turnover with relation to the spread of the coronavirus, may file an application for benefits meant to protect jobs, for payment of funds from the Guaranteed Employee Benefits Fund to be used to finance salaries of employees (using a wider term: hired persons) affected by the economic shutdown in consequence of COVID-19. The employer is also entitled to funds for payment of social security contribution for persons performing work for him. If the employees are restrained from work, the entrepreneur shall be simultaneously entitled to suspend contributions into the PPK, as this would be a situation of economic shutdown within the meaning of the Anti-Crisis Act of 2013.

\section{Conclusion}

The performed analysis leads to the conclusion that the non-performance of work by employees-despite remaining on standby, ready for work-caused by reasons independent of them entitles the employer, who fulfils conditions defined in the Anti-Crisis Act of 2013, both to aid benefits provided under this Act and to the exemption defined in Art. 25 (4) (1) of the Act on PPK. Similarly, in the case of an employer who experiences economic difficulties due to the occurrence of COVID-19. Provided that he observes the rules defined in the Anti-Crisis Shield, he can apply for financial support specified in Art. 15g of that Act. Moreover, on the basis of regulations from 2018, he does not finance contributions into the employee capital plan throughout the period of the economic shutdown.

De lege lata, the suspension of contributions into the employee capital plan is not available to an employing entity which does not have the status of employer, irrespective of whether the economic shutdown is introduced under the Anti-Crisis Act of 2013, or the Anti-Crisis Shield.

\section{References}

Baran K.W. (2020) [in:] K.W. Baran (red.), Tarcza antykryzysowa 1.0-4.0. Ustawa o dodatku solidarnościowym i inne regulacje. Szczególne rozwiązania w prawie pracy, prawie urzędniczym i prawie ubezpieczeń społecznych zwiąane z COVID-19. Komentarz, Warszawa. 
Bigaj W. (2020) [in:] K.W. Baran (red.), Tarcza antykryzysowa 1.0-4.0. Ustawa o dodatku solidarnościowym i inne regulacje. Szczególne rozwiązania w prawie pracy, prawie urzędniczym i prawie ubezpieczeń społecznych związane z COVID-19. Komentarz, Warszawa.

Kijowski A. (1978) Pracowniczy obowiązek gotowości do świadczenia pracy, Poznań.

Pisarczyk Ł. (2013) Przestój ekonomiczny i obniżony wymiar czasu pracy - powrót do znanych instrumentów antykryzysowych, "Monitor Prawa Pracy," No. 12.

\section{Court sentences}

Judgment of the Supreme Court of 24 October 1997, I PKN 280/97, OSNP 1998, No. 15, item 453. Judgment of the Supreme Court of 16 August 2005, I PK 32/05, OSNP 2006, No. 11-12, item 184. Judgment of the Supreme Court of 7 January 2014, I PK 150/13, OSNP 2015, No. 3, item 35. Judgment of the Supreme Court of 7 July 2016, I PK 185/15, LEX 2111405.

Judgment of the Supreme Court of 25 October 2016, I PK 255/15, LEX 2155205.

\section{Legal acts}

The Labour Code Act of 26 June 1974, Dz.U. 2020, item 1320 consolidated text.

The Act of 23 May 1991 on Trade Unions, Dz.U. 2019, item 263 consolidated text.

The Act of 13 October 1998 on the Social Insurance System, Dz.U. 2020, item 266 consolidated text.

The Act of 11 October 2013 on special solutions tied to protection of jobs, Dz.U. 2019, item 669 consolidated text.

The Act of 4 October 2018 on Employee Capital Plans, Dz.U. 2020, item 1342 consolidated text.

The Act of 16 May 2019 on amendment of the Act on employee capital plans, the Act on the organization and functioning of pension funds and the Banking Law Act, Dz.U. 2019, item 1074.

The Act of 31 March 2020 on amending the Act on special solutions associated with the prevention, counteracting and control of COVID-19, other infectious diseases and the crisis situations they cause, as well as certain other acts, Dz.U. 2020, item 374 as amended. 